\title{
IP $\mathbb{R}$ Z
}

\section{WIELKOŚĆ KAPEAŃSTWA WEDEUG ŚW. AUGUSTYNA* (Epistola 21)}

IV $s$ t $\&$ p

Zimi 390/391 św, Aurustyn udaz sie z Tagasty do Hippony ${ }^{1}$, aby tan załozyć klasztor 1 służć radz pewnemu urzẹunikowi adninistracji /tzw. "agens in rebus"/, należacenu do tajnej policji cesarskiej3. Człorlek ten bowiem zamierzał wstapić do wspólnoty konteriplacyjnej, którł założy św.Augustyn. Czytyıano już wówczas jego pierwsze dialogi ułozone jeszcze w Casslclacum jak: "Przeciv akademikom" 1 "0 zyciu szczęśliwym" napisane w $386 \mathrm{r}$, "Soliloquia" z roku 386/387, "O nieśniertelności duszy" skomponowane iv $387 \mathrm{r}$. " Nodiolanie, a szczegóinie trantaty napisane w Tagaście w 388/389

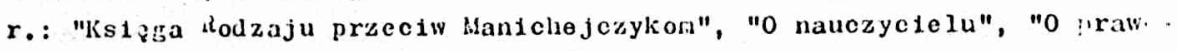
dzivej roligil". Znalazłszy się zaś w Ilpponie uczęszczał pilnie aa

$x$ Przekradu dolsonano z racińskiego tekstu krytycznego opracowanego procz A. Goldbachera, Sanct durelid augustini bistolae, Vindobonae $1895, \operatorname{cscl} 34 / 1,49-54$. Tytuty roziziałów pociodza od tłumacza.

1 Por. O.Perler, Les voyagos de St.Augustin, Paris 1969, 151-152.

2 Serio 35j,2, PL 39,1509: "Jalso arodziontec praybyłew do tego m1asta /lippony/, jak to zroszt.t ivielu z was o tym wie. Poszukiwałem tu micjsca, gdzlobyiu mó:z załozyć klasztor 1 żyć ze sirymi brać$\mathrm{min}$.

3 Possidius, Vita Sancti Aurelil tugustini 3, PL 32,36, tius. J.Ujia / Lywot świ:te:go Nurustyua, Poznaí 1930, POK 11/ s.XXXIXXL: "Zilirzylo gla proypadkien ir tyta samy czasie, ze jeden z tych, ktorych nazywaj. dontiand cesirskiwi/czyld czlonkaul tajnej policji cosarskicj, por. Sw. dugustyn, "yznania, tlun. z. Fublak, liarsana 19022,140 , uw. 27; P.Courcelle, "echerchos sur les 
liturgie. Ntejscory biskup Waleriusz, z pochodzenia Grek, nie znajazcy dobrze jezyka kacinskiego 1 punjekiego ${ }^{5}$, uskarżał się często wobec ludu na brak kapłana, który wspomagałby go w pracy kaznodzlejskiej ; z ponocz przyszit mu wiorni. Znald bowlem juz dobrzo program życia 1 nauk1 przebywającego wśród nich Augustyna, wiornço nasiladorcy sposobu życia 1 reguły ustalonoj przez Apostołów ${ }^{\top}$. Zwrócili sie więc do niego, zinusili go 1 siłą zaproiradzili - jak to siz juz niejednokrotnie zdarzało do biskupa, by ten wyświecil go na kapłana 8 . W czasie tego "gwałtu" Augustyn rzewnie płakał. Niektórzy nie rozumiejizc znaczenta tych zez, tłunaczyli je jako oznakę pychy 1 wyjaśniali mu, że choć jest on godzien o wiele wyzszego stopnia niź kapłaństro, to jednak $i$ ono zbliza go do biskupstra ${ }^{9}$.

Confessions de St.Augustin, Paris $1968^{2}, 181-182 /$, przebywający w Uipponie Królerskiej zacny 1 bogobojny chrześcijanin usłyszairszy o jego / Augustyna/ dobrej sławie 1 nauce, zapragnąz 1 życzył soble go widzieć, spodziewajzc siq, że bqdzie mógł wzgardzić rozkoszani 1 ponętami tego świata, jeżeli zasłuży sobie kłedyś usłyszeć słowo Boże z jego ust.' Gdy Augustynowi o tym dokładnie comiesiono, on pragnizc uwolnić duszą od ntebezpieczeńst. tego życia i od wiecznoj śmierci, zaraz przybył z własnej woll do rspomianego miasta /Hippony/' 1 dłuzej do poznanego człowieka przcinawiał i zachęcał go, lle Bóg pozwalał, aby spornit to, co Bogu ślutuował.

4 Tanże 4, PL 32,36-37, Ujda XL: "W tym to ezasie waadze b1skupia w Kościele hipponeńskim sprawował swiątobliwy Waleriusz. On to wskutek naglazcej potrzeby kościelnej przenawiał do bogobojnego ludu w sprawio upatrzenia kapłana dia miasta".

5 Tamże 5, PL 32,37, Ujda XLII: "On Naleriusz/ z pochodzenia Grek 1 niciviele obeznany z jezykiem 1 litoratura łacińska mnioj sie nadarał" do kaznodziejstwa. A. Arnauld w oparciu o list. Augustyna do Nowata/Ep. 84,2, CSEL $34,393 /$ wy sunzz hipoteze o nioznajomości jezyisa punickiego przez lialeriusza. Por. Possidius, Vita di San igostino, ed. e trad. L.Pellegrino, Alba 1955, 204,
n.3.

6 Possidius, dz.cyt. 5, PL 32, Ujda XLII: "Opowladal Naleriusz/, ze Pan rysiucial jego próśb, jakio do joga bardzo czesto zanosil, by mu zesłał takiego czlowicka, który by 1 słowem jónym 1 zdrowa naukił mógł budować Kościól Pariski".

7 Sermo $355,2, \mathrm{PL} 39,1569$ : "W1 ec10 wszysoy, albo prawio wszyscy, zo

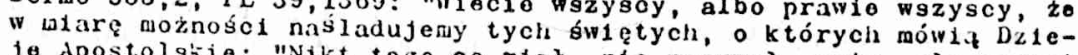
jo Apostolstie: "Nikt tego co miak, nie nazywar sivolm, ale wszyst-

8 Por. Possidius, dz.cyt. 4, PL 32,37, Ujda XLI.

9 Tarze: "Nicktórzy wprawdzie łzy jego, jak san mi to opoiriadar, tłunaczyli wedy pycha 1 joliby go pocieszajic morild, zo 1 stino- 
Augustyn czuł sia niegoinym tak wielkiego zaszezytu, płakaz i wyolbrzyriat vielkośc oraz mogośc ntebezpicczeristw, wynikających z zarzauzania 1 kieromania Kościotem. Jego powyzsze przosycla opisał póżniej Possydiusz.

lialeriusz przyjaz z radośctia propozycja ludu 1 ryśrigeił Alugustyna na kapłana w styczniu 391 roku ${ }^{10}$. Z tego właśnie czasu, z początku $391 \mathrm{r}$. pochodzi prezentowany przez nas 11st, w którym świeźy nooprezbiter, przejety 1 lelkościaz obowiazlór kapłańs'ich, prosi hialoriusza o nieco czasu ${ }^{11}$, by móc sią przygrotować do wykonywania swoich nowych zadań kapłańskich.

\section{b 1 b 1 l 0 g $r$ a 1 i a}

M.Pellegrino, Il sacerdozio nell' esperienza e nel pensiero di Sant Agostino, "Seninarium" 15/1963/z.2,1-20. J.Pintard, Le sacerdoce selon S.Augustin, Mane 1960 .

$$
P \text { r z e k } z \text { a d }
$$

Augustyn kapłan pozdraira w Panu błogosławionego i czcigodnego wobec naszego Pana szozerze ukochanego 0jca Biskupa Waleriusza.

wisko kapłana, choc1az on wyższego jest godny, zbliza do godnośc1 biskupiej. Ow zaś sługa Boży, jak nam opowiadał, z większym zastanorionlem sis namyślał i wzdychaz, widząc jak liczne 1 wielkle nlebezpieczeństwa grożz juz 1 wynikaja $z$ władzy $i$ zarządu Kościołen 1 dlatego płakaz".

10 Do dzloza F. Van der Meera, Saint Agustin pasteur d'âmes, Parıs 1959 , t.1,25 zakradł się błąd podajizcy lato 391 r. jako pors, podczas której iraleriusz wyświęcił Augustyna na kapłana. Augustyn bowien wyskal nasz list do Waleriusza w stycznfu $321 \mathrm{r}$. Por. S.Agostino, Lo Letterc, lowa $1369, t .1,100=$ przed Pielkanoca $391 /$..Carozzi/; 0.Perler, dz.cyt. $435=$ styczeń 391 r.; A.tiandouza, Prosopographle chrétienne du Bas Eapire, Paris 1982, 1140 $=$ r. 391 .

11 Waleriusz zgodzil siq na to przed Wielkanoç, która w $391 \mathrm{r}$. przypadała na 6 kwietnia. Poniewaz zaś ceremonia przokazania Symbolu kandydatom do chrztu miała miejsce w przeddzié́ IV niedzieli Wiolkiego Postu w sobote 15 marca, wnioskujemy, ze do togo czasu iarustyn ukoniczyl swe przygotowania do wykonywania obowi.jzkow kaplallsich 1 przoprowadzil sie do IItppony. Por. 0.Perler, dz.cyt. 152 . 


\section{A. Zadania kapłana sa niebezpleczne}

1. Proszq cie przede wszystisim, abyś w swej poboznoj roztropności ponyślał, że w tya życiu, a szozégúlnie "obecnym czasie, nio ma nic łatwiejszego, przyjenniejszego 1 bardzicj poszukiwanego w op 1 nil ludzkiej, jak urzįd biskupa, kapłana lub liakona, zaisładając, żo chcił ont swe czynności wykonywaó niedbale 1 z pochlebstiaml. Wobec Boga nie nia jednak nic bardziej nędznego, smutnego 1 bardziej godnego potępienia. Nie ma równié w tym zyciu, a szczególnie za naszych unt, nic bardziej trudnego, mozolnego 1 bardziej niebezpiecznego, niż urzįd biskupa, kapkana lub diakona. Przed Panem jednak nie ma nic bardziej szczéśliwego nlz bojorranie /1 Tm 1,18; $2 \mathrm{Tm} 2,4 /$ pod rozkazami naszego naczelnego wodza /Boga, Ale ant w dzieciństwie, an1 w modośc1 nie nauczyłen sie tego rodzaju słuzby ${ }^{1}$. Kiedy zaś zacząłcm sił jej uczyć, zmuszono mnie z powodu molch grzechów, 1 to słusznie, bo nie znam innej przyczyny, aby zaj:zł drugle miejsce przy sterze, ja, który nie uniałem navet wioser trzymać.

\section{B. Swi cenia kapłaískle przyjmowal Augustyn z płaczem}

2. Pan móf Jednak, jak sădzę, chcial mnle przoz to poprawić, poniewás ośmieliłem siz krytykować słabości wielu zeglarzy. Fiyobrazalea sobie bowien, że jestem bardziej niz ont uczony 1 pobozny, zania dosiviatezylon ich trudnych obowizzzków. Kledy doptero rzucono mic w środek worza, wtedy zaczałem rozumieć lokkomyślnosć mych zarzutów, chociaż 1 przedtca ưażałem to zadanie za bardzo niebozpioczne. oto proyczyna "owych łez", które wylałcm v mieście podezas molch niedawnych święceí. Niektúrzy z braci widziel1 moje $\mathbf{z y}$, a nio znając przyczyny mego bóli, pocieszali mnie w dobrej intoncji słowami nie majizcymi nic wspólnço z moin clerplenied . Doświadczyłem jednak o wiele wigcej trudnośc1, niz sig apodzierałen: nie zebya nio wldziat jalitehs nowych fal 1 nie slyszał burz, krórych bym przedtea nie znał, and o nich nio słyszal, nie czytar 1 nie mysial, ale wy-

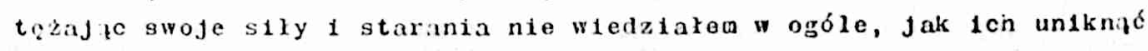

1 Wyznanda dugustyna nie nie suowit o jaklchkolwiek jego skłonnosclach do kaplanstwa ani ir czasie dzlectístira ani podczas arodosici.

2 W H1pponto.

3 Por. Pog:31dius, dz.cyt. 4, PL 32,37, Ujda XLI. 
albo przozwyciezzé i przyoisywałem dm pewno znaczenie. Pan zaś szydzj.ł ze lunie i poprzez te wydarzenia cheial mi ukazać nojí nicość.

 stira}

3. Jeśl1 zaś Pan to uczynił, to nie po to, by mie potęplać, ale po to, by at okazać swoje miłosierdzie. Z całaz pevnościa spodziewatu sia toro, zo poznawszy teraz swojaz chorobe, wintenem szukać

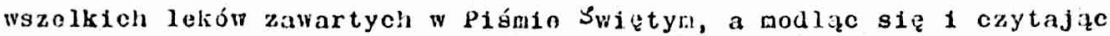
zabiegac o to, by Pan udzieliz mojej duszy odpowiedniego zdrowia do podjęcla tak nlebezpiocznych zajé; nie czyniłem przedtem tego, bo 1 czasu nto miałen. Iftedy bowicn zostałem wyśvi zcony na kapłana, kiedy myślałem o wolnej chwili potrzebnej do poznania Pisna św.; tak bowlem chcieliśmy sobiz zadysponować, abyśny mogli micé wolny czas na to zajocic. Szczera to prawda, ale nie wiedziałcu jeszeze czego mi brakuje do takiej pracy, Jaka na mnie obecnie ciaży i mnie wyczerpuje. Ir sanef bowlem rzcezy doriedziałem sie, co jest potrzebne człowickowi, który jest szafarzem sakranentu i słowa Bozego dla ludu, a juz niestety nie moge osi zgną́ tego, czego brak sobie uświadolailem. Ojcze lvaleriuszu, czy pragniesz moj zguby? Gdzie twoja miłość? Czy rzeczywiście unie kochasz? Czy rzeczywiście kochasz sam Kośoiót, któremu zgodnie z twoja wola man słuzyé? Powny jednak jesten, że kochasz 1 mnic, 1 sam Kościóz. Uznajesz mnie za zdatnego, choć ja sleblo lepioj znam, a przeciez nie znatbym slebie sancgo, jeślibym sieble wplorw nie dośwladezyl.

\section{Prośba o czas niozbedny na modlitwe 1 studiuin Pisma siw.}

4. Locz moze powio Twoja Swlątobliwośc: chclarbym wiodzieć, czeso brakuje Twnuu rykształceniu? otóz tyle mam braków, zo lativej


natomiast powtudzici, to wien $i$ wełni wierze to, co jest wyagane do naszego zbawlonia. If jak jednak sposób man tyı poslugiwać się dla zbillienia innych "nio szukajicc tego, co dla mnie jest potrzebne, alo co dla wielu, aby byl1 zbatrieni" / 1 Kor $1,33 /$ ? Moze w Ksiegach Swi tych znajdujt sis jakios rady, 1 nie volno w to watple, ze po zapoznaniu elo z nial 1 zrozumientu 1ch, mógłby człowiek Bozy dobrze 
wykonywać funkeje kośctelne, albo przynajmniej potrafilby pęlzić zycie wíród bezbożnych w wiekszym spokoju suntenia lub unrzeć tak, zeby nie stracić swero życia, do którego wzdychaja pokorne chrzé́cijaískie 1 lagodne serca. W jaki jednak sposób moze się to dokonać, jeślt nic wedlü zalecenia Pana: prosząc, szukając 1 kołacząc Mt 7,7-8/, to znaczy modlazc się, czytajzc 1 placząc? Na to wzaśnte zajacio chclałem sobie uprosić za pośrednictwen bract od Twej najszczerszej 1 czcigodnej Miłości nieco caasu, na przyátid az do Wielkanocy, 1 obecnte chcis ponowić swą prośb̨.

\section{E. Surowy sizu Boży czeka kajłana nozba:vionego świetej wiedzy}

5. Bo cóż odpowiem sądzazcesnu mnie Panu? Czy to, ze nio mogłem już wiecej tych rzeczy zgłęblać, pontewaz przeszkadzały mi w tysn sprawy Kościoła? On jednak możo mi poiviedzieć: "Sługo niegodziwy / It 18,32; Lk 19,22/, a jeśliby ktoś usiłovał zagarnać posiadłość kościelną, z której zebrante plonów wymagało cieźkioj pracy, zaniedbując przez to pole, które własna krwia zrosiłem, to jeślibyś uznal, że dla jej ratowania mozesz coś zrobić u sędziego ziemskicgo, czy nie pospieszyłbyś do niego za zgoda wszystíich, a nawet na polecenie lub pod przymusem niektórych? Jeśliby zaś wyrok sądu wypadł dla ciebie niekorzystnie, to czy nie podażłbyś nawet za morze? ${ }^{4}$ I takin wypadku nikt by sie nie skarzyl na twoja nieobecność, navot jeśliby ona trwała rok tub więcej, aby tylko ktoś inny nie posiadał ziemi zapewniajzcej zywność nio duszy, ale clału ludzi ubogich. Icli głód jednak o wiele zatwioj 1 dla mnie przyjemniej mogłyby zaspokolé noje zywe drzewa, jeśliby tylko by rannie pielignowane. Dlaczego wigc przytaczasz jako pretekst, zo brak c1 wolnego czasu, abysa siz nauczyz uprawy nojego pola?" Powiedz un prosz;, co man na to odpowiedzieć? Czy mozo chcesz, bym odpo:iedział: Stary "aleriusz bąice przekonany, se jestem wyksztazcony we wszystkim, o ile wigcej mnie ukochał, o tyle mnioj mi pozwolil nauczyć sie tycir rzeczy.

F. Ponowna nrosiba o litośc 1 wyrozuratenio

6. Starcze lraleriuszu, zwróć na to wszysiko swojt uwage. Za-

4 Tzn. do trybunaxu cesarsklogo myalo. 
klinam $C_{1 e}$ przez dobroć 1 surowośc Chrystusa, przez Jego nilosierdzie 1 sprawiedliwośc, 1 przez l'ego, który clq natchnłł tak wielkik filiościz wobec nas, zo nawet ze względu na dobro naszej duszy nie ośmelamy się ciebic urazió. Boga 1 Chrystusa wzywasz dla mnio na św ladka czystości sivolch intencji, miłośc1 oraz szczerych uczuć, jakie zywisz dla nas, jakobym ja nio mógł togo potwierdzić przystęga wobec wszystkich. Błagam vį̧c o te sama miłość 1 uczucio, abyśs ulitował sie nado mniz, 1 na to, na co cle prosiłem, udzielił mi tylo czasu, 110 prosiłein, oraz zebyś mnie wsponógł swymi mod11 twaml, aby nio było prózne moje pragniente 1 bezowocna moja nieobecność dla Koścloza Chrystusowego oraz dla pozytku brac1 1 współsług moich. Wiem, ze Pan nie wzgardzi taką miłośoią prosząca za mnio zwaszcza w takiej sprawie, ale przyjmując jt jako przyjemna oflarz, moze jeszcze wrótszyin czasie niż prosiłen, zapozna runie ze zbawiennymi radami Pisma Swigtego.

Tłum. 1 oprac. Ks. Wackaw Eborowicz - Pelplin

DE MAGNITUDINE SACEHDORII SECUNDUM S.AUGUSTINUM /Ep. 21/ /Sunmarium/

Huo legentibus priman epistulae XXI a $\$$. Augustino ad $\mathrm{Va}-$ lerium op1scopum, suum praedecessorem Ianuario AD 391 missae Polonam translationes prodimus, quan brevibus verbis introducinus, ut occasionem sacerdotalis Augustinl ordinationis exponamus. 